\title{
Microleakage of Class- $V$ Composite Restorations with Different Bonding Systems on Fluorosed Teeth
}

Cigigdem Küçükeșmena, DDS, PhD

Hayriye Sönmezb ${ }^{b}$ DDS, PhD

\section{ABSTRACT}

Objectives: To examine the effects of dental fluorosis and total and self-etch bonding systems on microleakage of Class-V composite restorations in permanent molar teeth.

Methods: Teeth were classified as three main groups according to Thylstrup-Fejerskov Index (TFI) as TFI=0, TFI=1-3 and TFI=4. Total and self-etching/bonding procedures were determined for each main group. Total-etching procedures were acid-etching for $30 \mathrm{~s}$ and acid-etching for $60 \mathrm{~s}$ with Single Bond/total-etch bonding system. Self-etching procedure was applied with Prompt-L-Pop/ self-etch bonding system. 63 box-shaped Class- $V$ cavities $(4 \times 2 \times 2 \mathrm{~mm})$ were prepared on mid-buccal/ palatinal/lingual surfaces of teeth for totalling nine test groups $(n=7)$. Restorations with composite material (Charisma) polymerized with halogen unit for $40 \mathrm{~s}$. Teeth were thermocycled between $+5^{\circ} \mathrm{C}$ $-+55^{\circ} \mathrm{C}$ ( $\left.\times 500\right)$, immersed in $0.5 \%$ basic-fuchsin solution $\left(37^{\circ} \mathrm{C}, 24 \mathrm{~h}\right.$ ) and separated longitudinally in bucco-lingual direction. Dye penetration was examined under stereomicroscope (3.2x10).

Results: Microleakage levels were higher in teeth of $T F I=4$ than $T F I=0$ occlusally or cervically $(\mathrm{P}<.05)$. In TFI=0; total-etched teeth for 30s have statistically shown more leakage than total-etched teeth for 60s occlusally or cervically $(P<.05)$. In TFI=4; microleakage levels were significantly higher for 30 s than 60s cervically $(P<.05)$. For all TFI levels, microleakage was commonly increased with self-etch system than total-etch system $(P<.05)$. Generally, higher leakage was present at cervical margins than occlusal margins $(P<.05)$.

Conclusions: Microleakage has increased by severity of dental fluorosis. Generally, more leakage was observed in total-etched teeth for 30s than 60s. Microleakage was commonly higher in selfetched teeth than total-etched teeth. More leakage was present at cervical margins than occlusal margins. (Eur J Dent 2008;2:48-58)

Key words: Class-V restorations; Composites; Dental fluorosis; Microleakage.

\section{INTRODUCTION}

Anti-cariogenic and positive effects of fluorides

a Assist. Prof., Department of Pedodontics, Faculty of Dentistry, Suleyman Demirel University, Isparta, Turkey.

b Prof., Department of Pedodontics, Faculty of Dentistry, Ankara University, Ankara, Turkey.

- Corresponding Author: Cị̄gdem Küçükeșmen Süleyman DemirelUniversity, Department of Pedodontics, Faculty of Dentistry, 32260 Cünür, Isparta, Türkiye. Phone : +905374151110

Fax: +902462370607

E-mail: kucukesmencigdemagmail.com on teeth and carious lesions were proved in dentistry. ${ }^{1-4}$ However, common using of fluoridecontaining products such as foods, soft drinks, supplements and some dental materials have resulted in increased prevalence of dental fluorosis in many countries over the past few decades. ${ }^{5-8}$ Dental fluorosis is also endemic in several parts of the world. ${ }^{9-11}$

Fluorosed enamel is characterized by an outer hypermineralized surface and porosity of subsurface layer.' Fluorosed teeth sometimes 
need to be restored for functional or aesthetic reasons. ${ }^{6}$ Composite resin applications may be practiced for the treatment of moderately or severely fluorosed teeth. ${ }^{5}$ Composite restorations often depend largely on micromechanical retention obtained from etched enamel with the acid-etching technique which was first described by Buonocore. ${ }^{12}$ Hypermineralized surface of fluorosed enamel is difficult to acid-etch. ${ }^{13}$ Bonding of restorations on fluorosed teeth involves etching the acid-resistant enamel and may necessitate prolonging the etching time. ${ }^{9}$

Microleakage is the marginal permeability to bacterial, chemical and molecular invasion at the interface between the teeth and restorations. It may cause discoloration, recurrent caries and pulpal pathology. ${ }^{14}$ It was decreased by use of acidetching technique ${ }^{15,16}$ and bonding systems. ${ }^{15,17,18}$

Recently, bonding agents may be classified as total-etch (TE) and self-etch (SE) bonding systems according to their application steps. TE bonding systems are consisted of two or three application steps. First step includes an acidetching procedure. Following steps are composed by separated or combined applications of primer and adhesive solutions. SE bonding systems have self-etching efficiency on tooth structures. 2 step SE adhesives rely on the use of a separate selfetching (which is combined to the priming step) before application of the resin. ${ }^{19-21}$

Our null hypothesis is that, dental fluorosis and different etching/bonding procedures may affect microleakage levels of Class $V$ composite restorations on permanent teeth. The purpose of this in-vitro study was to examine the microleakage of Class- $V$ composite resin restorations using total and self-etch bonding systems on fluorosed permanent molar teeth.

\section{MATERIALS AND METHODS}

In study, freshly extracted, non-carious, fluorosed molar permanent teeth were used. All teeth were cleaned, polished and immersed in distilled water containing $0.1 \%$ thymol solution, and stored in distilled water in room temperature until used. Teeth were classified according to Thylstrup-Fejerskov Index (TFI) ${ }^{22,23}$ (Figure 1) and separated into 3 main groups as $\mathrm{TFI}=0, \mathrm{TFI}=1-3$ and $\mathrm{TFI}=4$.

Two different bonding systems with different etching procedures were used;

- Single Bond (SB) (3M, St Paul, MN, USA, Lot no: 55144) / TE system: SB was applied with different etching times of 30 seconds (s) and 60 s with a $35 \%$ phosphoric acid etching-gel (Multipurpose Etching Gel; 3M, USA, Lot no: 20020613).

- Prompt-L-Pop (PLP) (ESPE, Germany, Lot no: 118642) / SE system: PLP was directly applied without etching step separately.

All etching and bonding procedures were shown in Table 1. Group names were coded as $0 / 1 / 4$ and $a / b / c$ where numbers represent the TFI scores. Small letters represent the bonding procedure including acid etching of enamel for $30 \mathrm{~s}$ and application of SB total etch bonding system (a), acid etching of enamel for 60s and application of SB total etch bonding system (b) and application of PLP self-etching bonding system (c).

Totally nine test groups were determined ( $n=7)$. All test groups were shown in Table 1. A total of 63 standardized, box-shaped Class-V cavities were prepared (sizes: $4 \mathrm{~mm}$ length $\times 2 \mathrm{~mm}$ width $\times 2$ $\mathrm{mm}$ depth) on the mid-buccal and mid-palatinal/ lingual surfaces of the randomly selected teeth by the same researcher. A high speed dental torque (KaVo Super Torque, Lux 2, 640 B, P 294779, Germany) and fissure diamond burs (North Bel, FG Coarse, lot no. 200000011267, Italyl were

\section{Thylstrup-Fejerskov Index (TFI)}

$\mathrm{TFI}=0$ : Normal view of enamel; translucent and shiny $T F I=1$ : White, thin, opaque lines on enamel surfaces.

$T F I=2$ : White, snowy and cloudy areas on incisal regions or cusps.

TFI=3: Connected wide opaque lines and cloudy areas on enamel surfaces.

TFI=4: A significant opacity on all enamel surface.

$\mathrm{TFI}=5$ : Pittings $(<2 \mathrm{~mm})$ on opaque enamel surface related to local loss of outer enamel.

TFI=6: Connected pittings and breaking of facial enamel on incisal regions or cusps.

TFI=7: Irregular loss areas on enamel surface (half and half).

$T F I=8$ : Commonly loss of enamel (more than half).

$\mathrm{TFI}=9$ : Generalized loss of outer enamel (much more than half), alteration of anatomical shape of tooth, remained cervical opaque enamel and dark-brown coloured tooth structure.

Figure 1. The criteria used for indexing. ${ }^{22,23}$ 
used. Burs were renewed after each five cavity preparations. Cavity margins were placed in enamel. Enamel margins were beveled with a $45^{\circ}$ angle. The depth of cavities was millimetrically standardized using a periodontal probe.

A composite resin restorative material (Charisma; Heraeus-Kulzer, lot no.110067, Shade A2, Germanyl was placed into the cavities with bulk-technique and polymerized using a halogen light unit (Hilux 200, Benlioglu Dental, Turkey, 450 $\mathrm{mW} / \mathrm{cm}^{2}$ I for $40 \mathrm{~s}$. All specimens were immersed in water at $37^{\circ} \mathrm{C}$ for 24 hours after finishing and polishing procedures with a polishing set (Softlex polishing discs; 3M, St Paul, Minneapolis, USA). Teeth were then thermocycled between water baths held at $+5^{\circ} \mathrm{C}$ and $+55^{\circ} \mathrm{C}$ with a transfer

0 No dye penetration.

1 Dye penetration at the $1 / 3$ initial side of the cavity wall.

2 Dye penetration at the $2 / 3$ middle side of the cavity wall.

3 Dye penetration at the $1 / 3$ last side of the cavity wall.

4 Dye penetration at the axial wall.

Figure 2. The scoring method of dye penetration according to Alavi and Kianimanesh. ${ }^{24}$ time of $10 \mathrm{~s}$ and a dwell time of 30 s for 500 cycles. A double coated nail varnish was applied to the whole surface of the teeth except for the restorations and approximately $1 \mathrm{~mm}$ of tooth surfaces adjacent to the restorations. Then, all specimens were immersed in $0.5 \%$ basic-fuchsin solution for 24 hours at $37^{\circ} \mathrm{C}$. After removal from the solution, the teeth were rinsed in tap water and embedded vertically in autopolymerizing acrylic resin blocks (Orthocryl EQ, Dentaurum, Germany) and separated in a bucco-lingual direction through the centre of each tooth with a watercooled diamond saw (Micracut Precision Cutter, Metkon, Turkeyl. The specimens were evaluated under a stereomicroscope at 32X magnification (Leica, MZ12/AG, Switzerland, CH 9435) for dye penetration. Dye penetration scores at cavity walls were determined occlusally and cervically according to Alavi and Kianimanesh ${ }^{24}$ (Figure 2). Kruskal-Wallis H-Test, Mann-Whitney U-Test and Wilcoxon Signed Range Test were used for statistical evaluation of results $(P<.05)$.

\section{RESULTS}

Significant differences were present between groups named 0, 1 and 4 occlusally and cervically according to Kruskal-Wallis Test (Table 2) ( $\mathrm{P}=.000)$. Comparisons between all test groups and the

Table 1. All test groups according to TFI levels / bonding / etching procedures with codes ( $\mathrm{n}=7$ ).

\begin{tabular}{llll}
\hline & & \multicolumn{2}{c}{ Bonding / etching procedures } \\
\cline { 2 - 3 } TFI levels & Groups a & Groups b & Groups c \\
\hline Groups 0 & Group 0a & Group 0b & Group 0c \\
Groups 1 & Group 1a & Group 1b & Group 1c \\
Groups 4 & Group 4a & Group 4b & Group 4c \\
\hline Groups 0: Non-fluorosed teeth in TFI=0 & & \\
Groups 1: Fluorosed-teeth in TFI=1-3 & & & \\
Groups 4: Fluorosed-teeth in TFI=4 & & \\
Groups a: SB total-etch bonding system / 30s acid-etching procedure & \\
Groups b: SB total-etch bonding system / 60s acid-etching procedure & \\
Groups c: PLP self-etch bonding system / no acid-etching procedure & \\
\hline
\end{tabular}

Table 2. Statistical differences between teeth in three levels of TFI for occlusal and cervical margins according to Kruskal-Wallis Test $(\mathrm{P}<.05=*)$.

\begin{tabular}{l|ccc}
\cline { 2 - 4 } & Chi-Square & $\mathrm{df}$ & $\mathrm{P}$ \\
\hline Occlusal & 34.52 & 8 & $.000^{*}$ \\
Cervical & 47.21 & 8 & $.000^{*}$
\end{tabular}


statistical differences were shown occlusally and cervically according to Mann Whitney U Test (Table 3) $(P<.05)$.

Microleakage was generally found less in groups named $b$ than groups named $a$. There were significant differences between group named $\mathrm{Oa}$ and group named $0 b$ for both occlusally $(P=.037)$ and cervically $(P=.015)$. Difference was not significant between group named $1 \mathrm{a}$ and group named $1 \mathrm{~b}$ occlusally ( $\mathrm{P}=$.054) or cervically ( $\mathrm{P}=$.091). Statistically less microleakage was observed in group named $4 \mathrm{~b}$ than group named $4 \mathrm{a}$ cervically $(P=.015)$. Microleakage levels were commonly increased in groups named $c$ than groups named $a$ and than groups named $b$ occlusally $(P<.05)$. The significant differences were between group named $\mathrm{Oc}$ and group named $\mathrm{Oa}(\mathrm{P}=.03)$, between group named $0 \mathrm{C}$ and group named $\mathrm{Ob}(\mathrm{P}=.002)$ occlusally. There were not significant differences between group named $1 \mathrm{c}$ and group named 1a $(P=.1)$ and between group named $4 \mathrm{C}$ and group named $4 a(P=.473)$ and between group named $4 \mathrm{C}$ and group named $4 \mathrm{~b}(\mathrm{P}=.08)$ occlusally. There was significant differences between group named $1 \mathrm{c}$ and group named $1 \mathrm{~b}(\mathrm{P}=.007)$. The significant differences were present between group named $0 c$ and group named $0 \mathrm{a}(\mathrm{P}=.037)$ and between group named $0 \mathrm{c}$ and group named $\mathrm{Ob}(\mathrm{P}=.002)$ and between group named $1 \mathrm{c}$ and group named $1 \mathrm{~b} \quad(\mathrm{P}=.001)$ cervically. There were statistically significant differences between group named $\mathrm{Ob}$ and group named $1 \mathrm{a}(\mathrm{P}=.002)$, between group named $\mathrm{Ob}$ and group named $1 \mathrm{~b}(\mathrm{P}=$.037) and between group named $\mathrm{Ob}$ and group named $1 \mathrm{C}$ $(P=.001)$ occlusally. Significant differences were found between group named $\mathrm{Ob}$ and group named $4 a(P=.001)$ and between group named $0 b$ and group named $4 \mathrm{~b} \quad(P=.002)$ and between group named $\mathrm{Ob}$ and group named $4 \mathrm{C}(\mathrm{P}=.002)$ occlusally. Differences were not significant between group named $\mathrm{Oa}$ and group named $1 \mathrm{a}(\mathrm{P}=.054)$ and between group named $\mathrm{Oa}$ and group named $1 \mathrm{~b}$ $(P=1)$ occlusally. The significant difference was present between group named $\mathrm{Oa}$ and group named 1c ( $=$ =.007) occlusally. Differences were not significant between group named $\mathrm{Oa}$ and group named 1a $(P=.872)$ and between group named $0 \mathrm{a}$ and group named $1 \mathrm{~b}(\mathrm{P}=.091)$ cervically. The significant difference was present between group named $0 a$ and group named $1 c(P=.006)$ cervically.
Statistically significant differences were present between group named $\mathrm{Oa}$ and group named 4a $(P=.004)$ and between group named $0 a$ and group named $4 \mathrm{C}(\mathrm{P}=.001)$ cervically. There were significant differences between group named $\mathrm{Ob}$ and group named $1 \mathrm{a}(\mathrm{P}=.015)$ and between group named $\mathrm{Ob}$ and group named $1 \mathrm{c}(\mathrm{P}=.001)$ cervically. The differences were statistically significant between group named $\mathrm{Ob}$ and group named $4 a \quad(P=.001)$ and between group named $\mathrm{Ob}$ and group named $4 \mathrm{~b}(\mathrm{P}=.004)$ and between group named $\mathrm{Ob}$ and group named $4 \mathrm{C}(\mathrm{P}=.001)$ cervically. Statistically significant differences were present between group named $4 \mathrm{C}$ and group named $0 \mathrm{C}(\mathrm{P}=.001)$, and between group named $4 \mathrm{C}$ and group named $1 c(P=.02)$ cervically. There were significant differences between group named $4 \mathrm{C}$ and group named $4 \mathrm{a}(\mathrm{P}=.02)$ and between group named $4 \mathrm{C}$ and group named $4 \mathrm{~b}(\mathrm{P}=\mathrm{.001})$ cervically. Statistically significant difference was present between occlusal and cervical margins $(P=.000)$. All results and statistical differences were shown in Table 2-6 and Figures 3 and 4.

\section{DISCUSSION}

In this study, the hypothesis was accepted that, dental fluorosis and different etching/bonding procedures affect microleakage levels of Class-V composite restorations on permanent teeth. Microleakage is examined with several in-vitro studies such as dye-penetration tests, chemically agents, compressed air, neutron activation analysis, bacterial studies, radioisotope materials etc. ${ }^{25-28}$. The most frequent using methods are conventional and dependable dye-penetration tests. ${ }^{29,30}$ Basic fuchsin (0.5-2\%), ${ }^{24,30-33}$ methylene blue $(0.2-2 \%),{ }^{34-40}$ silver nitrate $(50 \%),{ }^{41,42}$ crystal violet $(0.05 \%)$, eritrosin $(2 \%), 43$ and Rodhamine B $(0.2 \%)^{44}$ are commonly using dye-penetration solutions.

Recently, more improved another techniques are also used for determining the leakage of dental materials. For example; sliding of dental tissues and examination of leakage with ammoniacal $\mathrm{AgNO}_{3}$ solutions under scanning electron microscopy (SEM) using the backscattered electron mode ${ }^{45}$ or contemporary field emission in-lens SEM (FEISEM ${ }^{46,47}$ or transmission electron microscopy (TEM).45,46,48 Another new examination technique is confocal microscopy. It is for comparing with 
Table 3. Statistical differences between TFI / bonding / etching groups according to Mann-Whitney U Test for occlusal and cervical margins $(\mathrm{P}<.05=*)$.

\begin{tabular}{|c|c|c|c|c|c|}
\hline \multirow{2}{*}{\multicolumn{2}{|c|}{$\begin{array}{l}\text { Significant differences } \\
\text { between test groups }\end{array}$}} & \multirow{2}{*}{\multicolumn{2}{|c|}{ Values of Mann-Whitney U Test }} & \multicolumn{2}{|c|}{$\mathrm{P}<.05=*$} \\
\hline & & & & \multirow{2}{*}{$\begin{array}{c}\text { Oclusally } \\
.037^{*}\end{array}$} & \multirow{2}{*}{$\begin{array}{c}\text { Cervically } \\
.015^{*}\end{array}$} \\
\hline \multirow{8}{*}{ Oa } & $\mathrm{Ob}$ & 10.5 & 7.5 & & \\
\hline & Oc & 10 & 10.5 & $.03^{*}$ & $.037 *$ \\
\hline & $1 a$ & 12.5 & 23.5 & .054 & .872 \\
\hline & $1 b$ & 24.5 & 15 & 1 & .091 \\
\hline & 1c & 5 & 5 & $.007^{*}$ & $.006^{*}$ \\
\hline & $4 a$ & 5 & 3 & $.006 *$ & $.004^{*}$ \\
\hline & $4 b$ & 12.5 & 14 & .054 & .122 \\
\hline & $4 c$ & 5 & 0 & $.007^{*}$ & $.001 *$ \\
\hline \multirow{7}{*}{$\mathrm{Ob}$} & Oc & 2 & 1.5 & $.002 *$ & $.002^{*}$ \\
\hline & $1 a$ & 2.5 & 7.5 & $.002 *$ & $.015^{*}$ \\
\hline & $1 b$ & 10.5 & 14 & $.037^{*}$ & .107 \\
\hline & 1c & 1 & 0 & $.001 *$ & $.001 *$ \\
\hline & $4 a$ & 1 & 0 & $.001 *$ & $.001 *$ \\
\hline & $4 b$ & 2.5 & 3 & $.002^{*}$ & $.004^{*}$ \\
\hline & $4 c$ & 1 & 0 & $.002^{*}$ & $.001 *$ \\
\hline \multirow{6}{*}{$0 c$} & $1 a$ & 21 & 13.5 & .591 & .116 \\
\hline & $1 b$ & 10 & 3 & $.030 *$ & $.002 *$ \\
\hline & $1 c$ & 16 & 15 & .225 & .091 \\
\hline & $4 a$ & 17.5 & 9 & .298 & $.020 *$ \\
\hline & $4 b$ & 21 & 21 & .591 & .53 \\
\hline & $4 c$ & 14.5 & 0 & .165 & $.001 *$ \\
\hline \multirow{5}{*}{$1 a$} & $1 b$ & 12.5 & 15 & .054 & .091 \\
\hline & $1 \mathrm{c}$ & 13 & 8.5 & .1 & $.028 *$ \\
\hline & $4 a$ & 14 & 6 & .122 & $.013^{*}$ \\
\hline & $4 b$ & 24.5 & 16.5 & 1 & .253 \\
\hline & $4 c$ & 12 & 1 & .08 & $.002^{*}$ \\
\hline \multirow{4}{*}{$1 b$} & $1 c$ & 5 & 0 & $.007^{*}$ & $.001 *$ \\
\hline & $4 a$ & 5 & 0 & $.006 *$ & $.001 *$ \\
\hline & $4 b$ & 12.5 & 6 & .054 & $.007 *$ \\
\hline & $4 c$ & 5 & 0 & $.007 *$ & $.001 *$ \\
\hline \multirow{3}{*}{$1 c$} & $4 a$ & 22 & 16.5 & .705 & .244 \\
\hline & $4 b$ & 13 & 12.5 & 1 & .054 \\
\hline & $4 c$ & 21.5 & 2 & .678 & $.020 *$ \\
\hline \multirow{2}{*}{$4 a$} & $4 b$ & 14 & 7.5 & .122 & $.015^{*}$ \\
\hline & $4 c$ & 19.5 & 7.5 & .473 & $.020 *$ \\
\hline $4 b$ & $4 c$ & 12 & 0 & .08 & $.001 *$ \\
\hline
\end{tabular}




\begin{tabular}{|c|c|c|c|c|c|c|c|c|c|}
\hline $\begin{array}{l}\text { Groups } \\
\text { (Occlusally) }\end{array}$ & $0 \mathrm{a}$ & $\mathrm{Ob}$ & $0 c$ & $1 a$ & $1 b$ & $1 c$ & $4 a$ & $4 b$ & $4 c$ \\
\hline $0 \mathrm{a}$ & & $*$ & $*$ & & & & & & \\
\hline $\mathrm{Ob}$ & $*$ & & $*$ & $*$ & $*$ & $*$ & $*$ & $*$ & $*$ \\
\hline $0 c$ & $*$ & $*$ & & & $*$ & & & & \\
\hline $1 a$ & & $*$ & & & & & & & \\
\hline $1 b$ & & $*$ & $*$ & & & $*$ & & & \\
\hline $1 c$ & & $*$ & & & $*$ & & & & \\
\hline $4 a$ & & $*$ & & & & & & & \\
\hline $4 b$ & & $*$ & & & & & & & \\
\hline $4 c$ & & $*$ & & & & & & & \\
\hline
\end{tabular}

Figure 3. Statistical differences between all groups locclusally) $\left({ }^{*}=P<.05\right)$.

\begin{tabular}{|c|c|c|c|c|c|c|c|c|c|}
\hline $\begin{array}{l}\text { Groups } \\
\text { (Cervically) }\end{array}$ & $0 \mathrm{a}$ & $\mathrm{Ob}$ & $0 c$ & $1 a$ & $1 b$ & 1c & $4 a$ & $4 b$ & $4 c$ \\
\hline $0 \mathrm{a}$ & & $*$ & $*$ & & & & $*$ & & $*$ \\
\hline $\mathrm{Ob}$ & $*$ & & $*$ & $*$ & & $*$ & $*$ & $*$ & $*$ \\
\hline $0 c$ & $*$ & $*$ & & & $*$ & & $*$ & & $*$ \\
\hline $1 \mathrm{a}$ & & $*$ & & & & $*$ & $*$ & & $*$ \\
\hline $1 b$ & & & $*$ & & & $*$ & $*$ & & $*$ \\
\hline 1c & & $*$ & & $*$ & & & & & $*$ \\
\hline $4 a$ & * & $*$ & $*$ & $*$ & & & & $*$ & $*$ \\
\hline $4 b$ & & $*$ & & & & & & & $*$ \\
\hline $4 c$ & $*$ & $*$ & $*$ & $*$ & $*$ & & & & \\
\hline
\end{tabular}

Figure 4. Statistical differences between all groups (cervically) $(*=\mathrm{P}<.05)$.

the current microscopic techniques for examining restorative dental procedures and dental materials and can be considered as being midway between optical and electron microscopy. ${ }^{49}$ This technique that can be used both in the clinic and the high resolution microscopy suite for fluorescent structures within semi transparent materials such as cells and dental hard tissues. ${ }^{50,51}$ The laser scanning type microscope (CLSM) and the realtime direct view of tandem scanning microscopes
(TSM) are basically two types of confocal optical microscope. ${ }^{49}$ All confocal scanning optical microscopes are suitable for making highresolution images of many structures in teeth under near normal conditions. The number of applications widens considerably if the microscope can operate at high speed. The high-frame speed of TSM enables real-time examination of teeth in vivo and experimental procedures examined microscopically on extracted teeth can include 
the observation of the fluid flow and application of adhesives. ${ }^{52}$ In addition, new imaging techniques such as multi-photon laser excitation of dyes give the potential of greater depth penetration and improved resolution. ${ }^{51}$ All these techniques are more sophisticated, relative and ultrainformative methods for leakage tests. However, these techniques require exhaustive equipments, detailed technical precisions and knowledge and rather expensive hardware. Therefore, using of these more advanced methods may not be easy by all researchers every time.

In this study, a conventional and dependable dye-penetration method with basic fuchsin solution was used for examination of microleakage. It was reported that, basic fuchsin may be prepared in $2 \%$ concentration, ${ }^{53}$ otherwise $0.5 \%$ concentration was generally preferred ${ }^{24,30-33,54}$ as in the present study.

One-slice cutting technique is common used in conventional dye-penetration/microleakage examinations under conventional microscopy. ${ }^{31-}$ 33,37-40,54-60 Also, more sensitive multi-slices cutting technique may be used for leakage studies, but this technique is usually preferred for more improved ultra-microscopical examinations e.g. SEM/TEM or confocal microscopy. ${ }^{45-47,49-52}$ In the present study, conventional one-slice cutting technique was used for conventional dye-penetration/ microleakage test. Already, multi-slices cutting technique may not be suitable for fluorosed teeth owing to their hypermineralized and very easily breakable enamel structure because of multislices cutting technique requires a series of very thin and smooth slices of tooth structures.

For composite restorations, incremental placement technique has been suggested to reduce microleakage ${ }^{28,59}$ and to produce greater resistance to cuspal fractures. ${ }^{61}$ Otherwise, it was reported that, bulk placement technique is also suitable for composite restorations of 2-mm thickness and this technique is commonly used in microleakage studies. ${ }^{17,33,34,38,39,42,62}$ In the present

Table 4. Descriptives for occlusal and cervical margins according to Wilcoxon Signed Rank Test.

\begin{tabular}{lccccc}
\hline Margins & $\mathrm{n}$ & Mean & $\mathrm{SD}$ & Min & Max \\
\hline Occlusal & 63 & 1.25 & 0.82 & 0 & 4 \\
Cervical & 63 & 1.81 & 1.08 & 0 & 4 \\
\hline
\end{tabular}

study, bulk placement technique was used in standardized 2-mm depth of cavities of composite restorations.

Marginal microleakage is an important factor which causes to the clinical failure of restorations. ${ }^{14,16}$ Some determinants may affect the microleakage such as structure of enamel, ${ }^{13}$ acid-etching time, ${ }^{15}$ bonding systems, ${ }^{17,18}$ cavity designs and C-factor. . $^{63,64}$

In this study, more microleakage was found in fluorosed teeth than non-fluorosed teeth and microleakage levels increased depending on the severity of dental fluorosis. These higher microleakage levels may be explained by a weaker bonding of composite restorations on fluorosed teeth because of the pitted and detachable fluoroapatite structure of fluorosed enamel which has hypermineralized surface layer and quite extensive subsurface porosity. ${ }^{?}$

In dentistry, using of the acid-etching technique has reduced the microleakage. ${ }^{15,16}$ However, demineralization rates of enamel is affected from the type and concentration of etching agents. ${ }^{65,66}$ Otherwise, the depth of etch of fluorosed teeth is influenced not only by the type and concentration of acid etchants, but also by the etching time and the chemical composition of the enamel. Because the fluoroapatite in the hypermineralized surface layer of fluorosed teeth is more resistant to acid dissolution than the hydroxyapatite in nonfluorosed teeth, it has often been suggested the etching time of fluorosed enamel be doubled. 6,13,67 Therefore, in the present study, two different acidetching times were applied on the fluorosed teeth with total-etch bonding system. Etching time of $30 \mathrm{~s}$ was applied as normal etching time, and etching time of 60s was applied as doubled etching time. In the study, less microleakage levels were observed in total-etch bonding groups with etching time of 60 s than total-etch bonding groups with etching time of $30 \mathrm{~s}$. These results on etching times of

Table 5. Statistical differences between occlusal and cervical margins according to Wilcoxon Signed Rank Test $(\mathrm{P}<.05=*)$.

Significant differences between occlusal-cervical margins

\begin{tabular}{ll}
\hline$Z$ & -4.19718 \\
$P$ & $.000^{*}$ \\
\hline
\end{tabular}


$60 \mathrm{~s}$ and 30 s supported the recommendations of previous researchers about doubled etching time on fluorosed teeth. $6,13,67$

The results of the study indicated that, microleakage scores were generally increased in self-etch groups than total-etch groups. Likewise, more microleakage was found with self-etch bonding systems in some previous studies. ${ }^{36,60,62}$ Bedran de Castro et al $^{58}$ reported that, a selfetching primer system obtained higher values of microleakage compared with an one-bottle totaletch system. Owens and Johnson ${ }^{59}$ observed in their study that, the use of a total-etch system significantly reduced microleakage than a self-etch system. In another study, Salim et al ${ }^{69}$ indicated that, the results suggested the application of a conventional two-bottle bonding system used with a total-etch technique is better than that of a selfetching adhesive system. In a different study, a multi-step total-etch adhesive system exhibited significantly less leakage at the enamel margin than the self-etch adhesive systems. ${ }^{57}$ Brandt et al ${ }^{56}$ reported in their study that, only two self-etch bonding systems between totaling six different self-etch bonding systems could be clinically acceptable alternatives to clinically proven a total-etch bonding system and the other self-etch products showed more microleakage. Deliperi et al $^{39}$ declared that, significantly more dyepenetration was observed in one-step self-etch adhesive group than another self-etch adhesives and a total-etch adhesive. On the other hand, some other studies indicated that microleakage was not found significantly different between self and total-etch bonding systems. ${ }^{41,43,70}$ Deliperi et al $^{55}$ reported in their study that, microleakage was not affected by the type of adhesive or its application technique. In another study performed by Santini et $\mathrm{al}^{,{ }^{71}}$ there was no significant difference in leakage between the self-etching groups and a total-etch group in enamel margins. In a study made by Owens et $\mathrm{al}^{57}$ there were no significant difference among the adhesive groups when the dentin margins were evaluated.

The results of the current study have supported the findings of previous studies about more leakage with self-etch bonding systems than total-etch bonding systems. ${ }^{36,39,56-60,62,69}$ Higher leakage scores in the present study may be related with inadequate demineralization of enamel by using self-etching bonding system. Additionally, the inefficiency of self-etching bonding system on fluorosed teeth may be related on hypermineralized / acidresistant enamel.

Finally, there are only two microleakage studies on fluorosed teeth in literature. ${ }^{68,33}$ Furthermore, there are not any study comparing total and self-etching/bonding systems or normal and prolonged etching times on microleakage of permanent fluorosed teeth. Therefore, the results of the current study are rather important for;

- Adding more knowledge on microleakage levels of composites on fluorosed teeth.

- Getting some information about microleakage levels of fluorosed teeth with different bonding systems.

- Supporting the suggestions of previous researchers about prolonged etching time on fluorosed teeth for better adhesion. 6,13,67

On the other hand, it has been reported that, leakage could not been completely eliminated in composite restorations even though using of totaletch bonding systems yet. ${ }^{24,34} \mathrm{Also}$, in the present study, microleakage could not been absolutely eradicated in spite of using of a total-etch bonding system in fluorosed or non-fluorosed teeth.

Microleakage levels were found higher at cervical margins than occlusal margins of teeth in this study $(P<.05)$. More leakage was also reported at cervical margins than occlusal margins in previous studies. ${ }^{24,72}$ The findings of the current study were parallel with their results. This condition may be explained with thinner and weaker structure of enamel at cervical areas.

$\mathrm{C}$-factor is defined as the ratio of the bonded surface area to the unbonded or free surface area. ${ }^{63}$ It may also play a role in marginal sealing. A high $\mathrm{C}$-factor is a risk in bonding procedure. Because increased polymerization stresses may occur by high rates of $\mathrm{C}$-factor.63,64 The box-shaped cavity design was recommended by some previous researchers in their studies to resemble most closely the clinical situation resulting in a $\mathrm{C}$-factor of about 3, where relatively high shrinkage stresses can be expected. ${ }^{30,73,74}$ Box-shaped cavity design was used to determine the $\mathrm{C}$-factor relatively in this study.

This study was performed on examination of microleakage levels of composite restorations with different bonding systems on fluorosed teeth. 
It is hoped that, the findings of the current study may help to next restorative studies on fluorosed teeth. However, these findings must be supported with other future researches.

\section{CONCLUSIONS}

1. Microleakage was found significant in fluorosed teeth than non-fluorosed teeth. Leakage was affected by dental fluorosis and increased by severity of fluorosis.

2. Generally less microleakage was observed at total-etch bonding groups with 60s etching procedure than total-etch bonding groups with 30 s etching procedure. 60 s etching procedure has reduced microleakage in particularly $\mathrm{TFI}=4$.

3. Commonly more microleakage was found in all self-etch bonding groups than total-etch bonding groups.

4. Generally more microleakage was observed in cervical margins than occlusal margins.

\section{ACKNOWLEDGEMENTS}

This study was made as second part of the PhD Thesis of correspondence author which was performed at Department of Paedodontics, Faculty of Dentistry, Ankara University, in April 2004.

\section{REFERENCES}

1. Bryant BS, Retief DH, Bradley EL, Denys FR. The effect of topical fluoride treatment on enamel fluoride uptake and the tensile bond strength of an orthodontic bonding resin. Am J Orthod 1985;87:294-302.

2. Whitford GM, Ekstrand J. Summary of Session I: Metabolism of fluoride. J Dent Res 1990;69:513.

3. Hallgren A, Oliveby A, Twetman S. Salivary fluoride concentrations in children with glass ionomer cemented orthodontic appliances. Caries Res 1990;24:239-241.

4. Croll TP. Light-hardened glass-ionomer-resin cement restoration adjacent to a bonded orthodontic bracket: A case report. Quintessence Int 1994;25:65-67.

5. Pang DTV, Phillips CL, Bawden JW. Fluoride intake from beverage consumption in a sample of North Carolina children. J Dent Res 1992;71:1382.

6. Al-Sugair MH, Akpata ES. Effect of fluorosis on etching of human enamel. J Oral Rehabil 1999; 26:521-528.

7. Leverett D. Prevalence of dental fluorosis in fluoridated and nonfluoridated communities-a preliminary investigation. $J$ Public Health Dent 1986;46:184-187.

8. Awliya WY, Akpata ES. Effect of fluorosis on shear bond strength of glass ionomer-based restorative materials to dentin. J Prosthet Dent 1999;81:290-294.

9. Ateyah N, Akpata E. Factors affecting shear bond strength of composite resin to fluorosed human enamel. Oper Dent 2000;25:216-222.

10. Dean HT, Arnold FA, Evolve E. Domestic water and dental caries. V. Additional studies of the relation of fluoride in domestic waters to dental caries in 4.425 white children, aged 12-14 years of 13 cities in 4 states. Public Health Report 1942;57:1155-1179.

11. Akpata ES, Fakiha Z, Khan N. Dental fluorosis in 12-15year-old rural children exposed to fluorides from well drinking water in the Hail region of Saudi Arabia. Community Dent Oral Epidemiol 1997;25:324-327.

12. Buonocore MG. A simple method of increasing the adhesion of acrylic filling materials to enamel surfaces. $J$ Dent Res 1955;34:849-883.

13. Opinya GN, Pameijer $\mathrm{CH}$. Tensile bond sttength of fluorosed Kenyan teeth using the acid etch technique. Int Dent $J$; 1986;36:225-229.

14. Wieczkowski G Jr, Yu XY, Davis EL, Joynt RB. Microleakage in various dentin bonding agent/ composite resin systems. Oper Dent 1992;(Suppl.)5:62-67.

15. Retief DH, Denys FR. Adhesion to enamel and dentin. Am J Dent 1989;2:133-144.

16. Barkmeier WW, Cooley RL. Laboratory evaluation of adhesive systems. Oper Dent 1992;(Suppl.)5:50-61.

17. Neme AL, Evans DB, Maxson BB. Evaluation of dental adhesive systems with amalgam and resin composite restorations: comparison of microleakage and bond strength results. Oper Dent 2000;25:512-519.

18. Hembree JH, Andrews JT. In vitro microleakage of several acid-etch composite systems. J Dent Res 1976;55:Special issue B. Abstract No:309.

19. Bouillaguet S, Gysi P, Wataha JC, Ciucchi B, Cattani M, Godin CH, Meyer JM. Bond strength of composite to dentin using conventional, one-step and self-etching adhesive systems. J Dent 2001;29:55-61.

20. Zheng L, Pereira PN, Nakajima M, Sano H, Tagami J. Relationship between adhesive thickness and microtensile bond strength. Oper Dent 2001;26:97-104.

21. Van Meerbeek, B, Vargas $M$, Inoue S, Yoshida $Y$, Peumans M, Lambrechts P, Vanherle G. Adhesives and cements to promote preservation dentistry. Oper Dent 2001;(Suppl.)6:119-144.

22. Thylstrup A, Fejerskov 0. Clinical appearance of dental fluorosis in permanent teeth in relation to histologic changes. Commun Dent Oral Epidemiol 1978;6:315-328.

23. Fejerskov, O, Larsen, MJ, Richards A, Baelum V. Dental tissue effects of fluoride. Adv Dent Res 1994;8:15-31.

24. Alavi AA, Kianimanesh N. Microleakage of direct and 
indirect composite restorations with three dentin bonding agents. Oper Dent 2002;27:19-24.

25. Taylor MJ, Lynch E. Microleakage. J Dent 1992;20:3-10.

26. Charlton DG, Moore BK. In vitro evaluation of two microleakage detection tests. J Dent 1992;20:55-58.

27. Bayne SC, Hermann HO, Edward J. Update on dental composite restorations. JADA 1994;125:687-701.

28. Puckett A, Fitchie J, Hembree J Jr, Smith J. The effect of incremental versus bulk fill techniques on the microleakage of composite resin using a glass-ionomer liner. Oper Dent 1992;17:186-191.

29. Kemp-Scholte CM, Davidson CL. Overhang of class V composite resin restorations from hygroscopic expansion. Quintessence Int 1989;20:551-553.

30. Friedl KH, Schmalz G, Hiller KA, Markl A. Marginal adaptation of Class $\mathrm{V}$ restorations with and without "softstart polymerization". Oper Dent 2000;25:26-32.

31. Attar N, Korkmaz Y. Effect of two-light-emitting diode (LED) and one halogen curing light on the microleakage of Class V flowable composite restorations. J Contemp Dent Pract 2007;8:80-88

32. Nalcaci A, Ulusoy $N$. Effect of thermocycling on microleakage of resin composites polymerized with LED curing techniques. Ouintessence Int 2007;38:433-439.

33. Küçükeșmen Ç, Sönmez H, Üșümez A, Küçükeșmen HC. Effects of dental fluorosis on microleakage from Class-V ormocer restorations in permanent molar teeth. Fluoride 2007;40:134-139.

34. Manhart J, Chen HY, Mehl A, Weber K, Hickel R. Marginal quality and microleakage of adhesive class $\mathrm{V}$ restorations. J Dent 2001;29:123-130.

35. Ferrari M, Vichi A, Mannocci F, Davidson CL. Sealing ability of two "compomers" applied with and without phosphoric acid treatment for Class $\mathrm{V}$ restorations in vivo. $J$ Prosthet Dent 1998;79:131-135.

36. Amaral CM, Hara AT, Pimenta LA, Rodrigues. Microleakage of hydrophilic adhesive systems in Class $\mathrm{V}$ composite restorations. Am J Dent 2001;14:31-33.

37. Owens BM, Johnson WW, Harris EF. Marginal permeability of self-etch and total-etch adhesive systems. Oper Dent 2006;31:60-67.

38. Deliperi S, Bardwell DN, Wegley C, Congiu MD. In vitro evaluation of giomers microleakage after exposure to $33 \%$ hydrogen peroxide: self-etch vs total-etch adhesives. Oper Dent 2006;31:227-232.

39. Deliperi S, Bardwell DN, Wegley C. Restoration interface microleakage using one total-etch and three self-etch adhesives. Oper Dent 2007;32:179-184.

40. Aranha AC, Pimenta LA. Effect of two different restorative techniques using resin-based composites on microleakage.
Am J Dent 2004;17:99-103.

41. Pontes DG, Tavares De Melo A, Monnerat AF. Microleakage of new all-in-one adhesive systems on dentinal and enamel margins. Quintessence Int 2002;33:136-139.

42. Heping LI, Burrow MF, Tyas MJ. The effect of load cycling on the nanoleakage of dentin bonding systems. Dent Mater 2002; 18:111-119.

43. Gordan VV, Vargas MA, Cobb DS, Denehy GE. Evaluation of asidic primers in microleakage of class $\mathrm{V}$ composite resin restorations. Oper Dent 1998;23:244-249.

44. Corona S, Borsatto Mc, Palma Dibb RG, Ramos RP, Brugnera A, Pecora JD. Microleakage of class $V$ resin composite restorations after bur, air-abrasion or Er:YAG laser preparation. Oper Dent 2001;26:491-497.

45. Reis AF, Arrais CAG, Novaes PD, Carvalho RM, De Goes MF, Giannini M. Ultramorphological analysis of resindentin interfaces produced with water-based single-step and two-step adhesives: nanoleakage expression. J Biomed Mater Res Part B: Appl Biomater 2004;71B: 90-98.

46. Suppa P, Breschi L, Ruggeri A, Mazzotti G, Prati C, Chersoni S, Di Lenarda R, Pashley DH, Tay FR. Nanoleakage within the hybrid layer: A correlative FEISEM/TEM investigation. $J$ Biomed Mater Res Part B: Appl Biomater 2005;73B: 7-14

47. Yuan Y, Shimada Y, Ichinose S, Tagami J. Qualitative analysis of adhesive interface nanoleakage using FE-SEM/ EDS. Dent Mater 2007;23:561-569.

48. Reis AF, Giannini M, Pereira PN. Long-term TEM analysis of the nanoleakage patterns in resin-dentin interfaces produced by different bonding strategies. Dent Mater 2007;23:1164-1172.

49. Watson TF. Applications of confocal scanning optical microscopy to dentistry. Br Dent J 1991;9;171:287-291.

50. Watson TF, Boyde A. Confocal light microscopic techniques for examining dental operative procedures and dental materials. A status report for the American Journal of Dentistry. Am J Dent 1991;4:193-200.

51. Watson TF, Azzopardi A, Etman M, Cheng PC, Sidhu SK. Confocal and multi-photon microscopy of dental hard tissues and biomaterials. Am J Dent 2000;13(Spec No):19D$24 \mathrm{D}$.

52. Watson TF. Applications of high-speed confocal imaging techniques in operative dentistry. Scanning 1994;16:168173.

53. Zyskind D, Frenkel A, Fuks A, Hirschfeld Z. Marginal leakage around V-shaped cavities restored with glass ionomer cements: an in vitro study. Quintessence Int 1991;22:41-45.

54. Araujo Fde O, Vieira LC, Monteiro Junior S. Influence of resin composite shade and location of the gingival margin on the microleakage of posterior restorations. Oper Dent 2006;31:556-561. 
55. Deliperi S, Bardwell DN, Papathanasiou A, Kastali S, Garcia-Godoy F. Microleakage of a microhybrid composite resin using three different adhesive placement techniques. $J$ Adhes Dent 2004;6:135-139.

56. Brandt PD, de Wet FA, du Preez IC. Self-etching bonding systems: In-vitro micro-leakage evaluation. SADJ 2006;61:248,250-251.

57. Owens BM, Johnson WW, Harris EF. Marginal permeability of self-etch and total-etch adhesive systems. Oper Dent 2006;31:60-67.

58. Bedran de Castro AK, Pimenta LA, Amaral CM, Ambrosano GM. Evaluation of microleakage in cervical margins of various posterior restorative systems. J Esthet Restor Dent 2002;14:107-114.

59. Owens BM, Johnson WW. Effect of insertion technique and adhesive system on microleakage of Class $\mathrm{V}$ resin composite restorations. J Adhes Dent 2005;7:303-308.

60. Hannig M, Fu B. Effect of air-abrasion and resin composite on microleakage of Class $\mathrm{V}$ restorations bonded with selfetching primers. $J$ Adhes Dent 2001;3:265-272.

61. Wieczkowski G Jr, Joynt RB, Klockowski R, Davis EL. Effects of incremental versus bulk fill technique on resistance to cuspal fracture of teeth restored with posterior composites. J Prosthet Dent 1988;60:283-287.

62. Luo Y, Lo ECM, Wei SHY, Tay FR. Comparison of pulse activation vs conventional light-curing on marginal adaptation of a compomer conditioned using a total-etch or a self-etch technique. Dent Mater 2002;18:36-48.

63. Feilzer AJ, de Gee AJ, Davidson CL. Setting stress in composite resin in relation to configuration of the restoration. J Dent Res 1987;66:1636-1639.

64. Kubo S, Yokota H, Yokota H, Hayashi Y. The effect of light-curing modes on the microleakage of cervical resin composite restorations. $J$ Dent 2004;32:247-254.

65. Brännström M, Nordenvall KJ. The effect of acid etching on enamel, dentin and the inner surface of the resin restoration. A SEM investigation. J Dent Res 1977;56:917923.

66. Brännström M, Nordenvall KJ, Malmgren 0 . The effect of various pretreatment methods of the enamel in bonding procedures. Am J Orthod 1978;74:522-530.

67. Christensen GJ. Clinical factors affecting adhesion. Oper Dent 1992;(Suppl.)5:24

68. Kırzıoḡlu Z, Özay Ertürk M, Karayılmaz H, Orhan H. Effects of dental fluorosis and salivary contamination on microleakage of four different restorative materials in primary molars. Fluoride 2006;39:220-227.

69. Salim S, Santini A, Husham A. A in-vitro study of microleakage around Class $V$ cavities bonded with a selfetching material versus a conventional two-bottle system.
Prim Dent Care 2006;13:107-111.

70. Gillet D, Nancy J, Dupuis V, Dorignac G. Microleakage and penetration depth of three types of materials in fissure sealant. Self-etching primer vs etching: an in vitro study. $J$ Clin Pediatr Dent 2002;26:175-178.

71. Santini A, Ivanovic V, Ibbetson R, Milia E. Influence of marginal bevels on microleakage around Class $V$ cavities bonded with seven self-etching agents. Am J Dent 2004;17:257-261.

72. Ozturk AN, Usumez A, Ozturk B, Usumez S. Influence of different light sources on microleakage of class $\mathrm{V}$ composite resin restorations. J Oral Rehabil 2004;31:500504.

73. Bausch JR, De Lange K, Davidson CL, Peters A, De Gee AJ. Clinical significance of polymerization shrinkage of composite resins. J Prosthet Dent 1982;48:59-67.

74. Kinomoto Y, Torii M. Photoelastic analysis of polymerization contraction stresses in resin composite restorations. $J$ Dent 1998;26:165-171. 